\title{
Leaf impressions of Terminalia (Combretaceae) and Daphnogene (Lauraceae) from the Middle Siwalik of the Chatara-Barahakshetra area, eastern Nepal
}

\author{
*Purushottam Adhikari ${ }^{1,2}$, Gaurav Srivastava ${ }^{3}$, Rakesh C. Mehrotra ${ }^{3}$, Drona Adhikari ${ }^{1,5}$, Keshav Shrestha ${ }^{1}$, Dieter Uhl ${ }^{4}$, and \\ Khum N. Paudayal ${ }^{1}$ \\ ${ }^{1}$ Central Department of Geology, Tribhuvan University, Kirtipur, Kathmandu, Nepal \\ ${ }^{2}$ Department of Geology, Birendra Multiple Campus, Tribhuvan University, Bharatpur, Chitwan, Nepal \\ ${ }^{3}$ Birbal Sahni Institute of Palaeosciences, Lucknow, India \\ ${ }^{4}$ Senckenberg Forschungsinstitut und Naturmuseum, Senckenberganlage 25, 60325 Frankfurt am Main, Germany \\ ${ }^{5}$ Department of Physics, Central Campus of Technology, Tribhuvan University, Dharan, Sunsari, Nepal
}

\begin{abstract}
Leaves of Terminalia (Combretaceae) and Daphnogene (Lauraceae) are described from the lower member of Lower Siwalik of ChataraBarahakshetra area, eastern Nepal. The habit, habitat and present day distribution of the comparable extant taxa indicates the existence of tropical to sub-tropical evergreen to semi evergreen forest with humid climate in the area during the deposition of the Siwalik sediments.
\end{abstract}

Key Words: Fossils, Terminalia, Daphnogene, Middle Siwalik, Late Miocene, eastern Nepal.

Accepted: 20 June 2018

\section{INTRODUCTION}

The Siwalik foreland basin accumulated a huge pile of molasse sediments since the middle Miocene to early Pleistocene between the Lesser Himalaya in the north and the Indo-Gangetic Plain in the south (Gansser 1964; Valdiya 2002). These fluvial succession consists of coarsening upward sequences as a whole but individual beds are fining upward on a scales of one to tens of meters (Nakayama and Ulak 1999). The Siwalik Group is also termed as the Churia Group in Nepal (Tokuoka and Yoshida 1984). The group is divided into two belts namely northern and southern belts, which are separated by the Central Churia Thrust (CCT of Tokuoka et al. 1986) and CCT is correlated to the Sit Khola Thrust (ST) of Dhital et al. (1995). During the early stage of the Siwalik research in Nepal, the three fold classification system (Lower, Middle, and Upper Siwalik) was commonly adapted (Auden 1935; Lombard 1958; Hagen 1969; Ithihara et al. 1972; Yoshida and Arita 1982; Kafle and Einfalt 1992; Schelling 1992; Ulak 2002, 2004, 2009). Several geologists provided local classification on the Siwalik Group on the basis of grain size and lithological characters (Tokuoka et al. 1986, 1988, 1990; Corvinus and Nanda 1994; Sah et al. 1994; Dhital et al. 1995; Ulak and Nakayama 1998; Sah et al. 2000a, 2000b, 2000c; Corvinus and Rimal 2001; Joshi and Dwivedi 2003; Sigdel et al. 2011; Adhikari and Sakai 2017). The fluvial sediments of the Siwalik yielded plant and animal fossils (West et al. 1978, 1991; West and Muthe 1981; Muthe et al. 1983; Awasthi and Prasad 1990; Sarkar 1990; Prasad 1990,

*Corresponding author

Email: puru11adhikari@gmail.com (P. Adhikari) 1994c; Konomatsu 1997; Prasad et al. 1997, 1999; Prasad and Pradhan 1998; Konomatsu and Awasthi 1999; Sah et al. 2000a; Hoorn et al. 2000; Corvinus and Rimal 2001; Prasad and Khare 2004; Prasad and Pandey 2008; Paudayal 2012, 2013a, 2013b). In the present communication, we report two plant megafossils recorded from the lower member of Middle Siwalik of Chatara-Barahakshetra area, eastern Nepal (Fig. 1). In the Chatara-Barahakshetra area a detailed plant megafossils study is still lacking. Therefore, this research is mainly focused on the identification of plant impressions recovered from this area.

\section{GEOLOGY OF THE STUDY AREA}

The structure and sedimentary facies of the Siwalik in Chatara-Barahkhetra area were studied by several authors (Bashyal 1980; Dhital 1992, 2015; Dhakal 2001; Ulak 2004). On the basis of lithostratigraphy, the Siwalik Group in Chatara-Barahakshetra area can be divided from bottom to top as the Lower Siwalik (Lower and Upper Members) and the Middle Siwalik (Lower and Upper Members). The Upper Siwalik is missing from the study area. The Siwalik rock is separated by the Main Boundary Thrust (MBT) from the Lesser Himalayan Precambrian dolomitic sequences and the Gondwana sequences in the north (Bashyal 1980; Dhital 1992, 2015) and by the Himalayan Frontal Thrust (HFT) from the Indo-Gangetic Plain in the south (Fig. 2).

\section{Lower Siwalik}

The Lower Siwalik is represented by very fine to medium grained sandstone interbedded with variegated mudstone and 
siltstone. The mudstone, siltstone, and sandstone are calcareous in nature. On the basis of thickness of sandstone and mudstone, grain size, composition, texture, it can be further subdivided into the lower and upper members.

\section{Lower member of Lower Siwalik}

It consists of variegated mudstone with dominance of bioturbation alternating with the dark grey, bluish grey, purple siltstone and very fine to fine grained light grey, greenish grey to dark grey sandstone. However, at some places medium grained dark grey sandstone is also found.

\section{Upper member of Lower Siwalik}

It consists of fine to coarse grained, light grey to dark grey sandstone alternating dark grey, greenish grey, bluish grey, violet siltstone and variegated to dark grey mudstone. The sandstone rarely shows 'salt and pepper' appearances but sandstone bed is more than mudstone beds. The contact between the upper member of Lower Siwalik and the lower member of Middle Siwalik is transitional.

\section{Middle Siwalik}

The Middle Siwalik is represented by fine to very coarse grained sandstone, pebbly sandstone interbedded with mudstone and siltstone. The calcareous cement is profusely present in mudstone, siltstone and sandstone. It is further subdivided into lower and upper members, on the basis of thickness of mudstone and sandstone, composition, grain size and texture etc.

\section{Lower member of Middle Siwalik}

It consists of medium to coarse grained, 'salt and pepper' and fine grained, dark grey sandstone interbedded with greenish grey, dark grey siltstone and dark grey mudstone. The mud clasts are found in siltstone and sandstone beds. The size of the clast is up to $1 \mathrm{~cm}$ in diameter.

\section{Upper member of Middle Siwalik}

It consists of coarse to very coarse grained, 'salt and pepper' grey sandstone, pebbly sandstone. The pebbly sandstone contains clast of quartzite, gneiss, and limestone and clast size is up to $2 \mathrm{~cm}$. The thickness of the sandstone beds may reach up to 30 meters. Sedimentary structures such as cross laminations, ripple marks, flute casts and convolute beddings are common in sandstone beds. Fine grained, bluish grey, dark grey, light grey, sandstones are frequently found interbedded with greenish grey, bluish grey, dark grey, black siltstone and dark grey mudstone. The plant leaf bearing horizon is found in the lower member of Middle Siwalik, Chatara-Barahakshetra road section, Satra Number and its lithological details and geological route map are shown in Figs. 3 and 4.

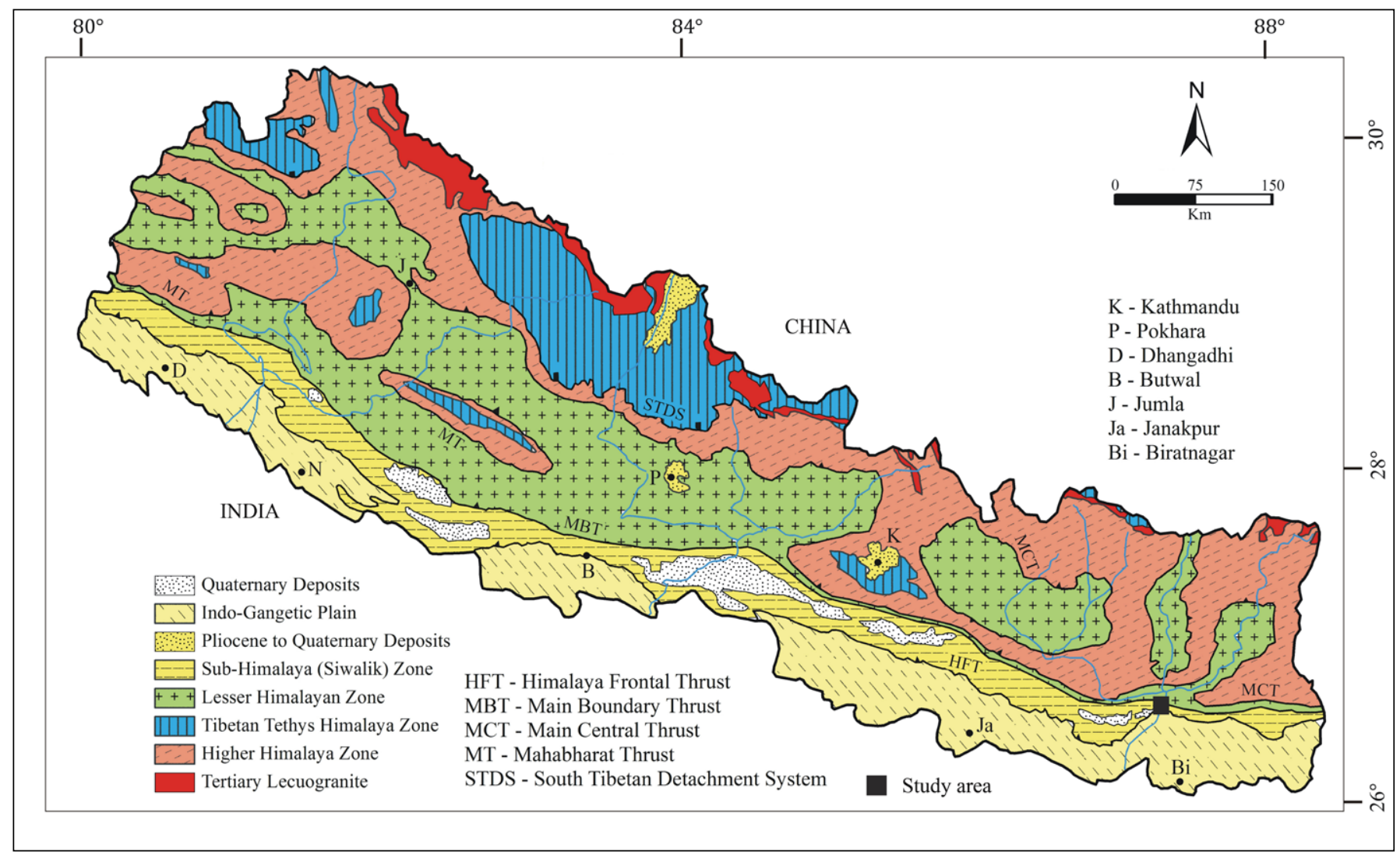

Fig. 1: Distribution of the Siwalik sediments in Nepal (modified after Martin et al. 2005). Black square indicates study area. 
Leaf impression of Terminalia (Combretaceae) and Daphnogene (Lauraceae) from the Middle Siwalik

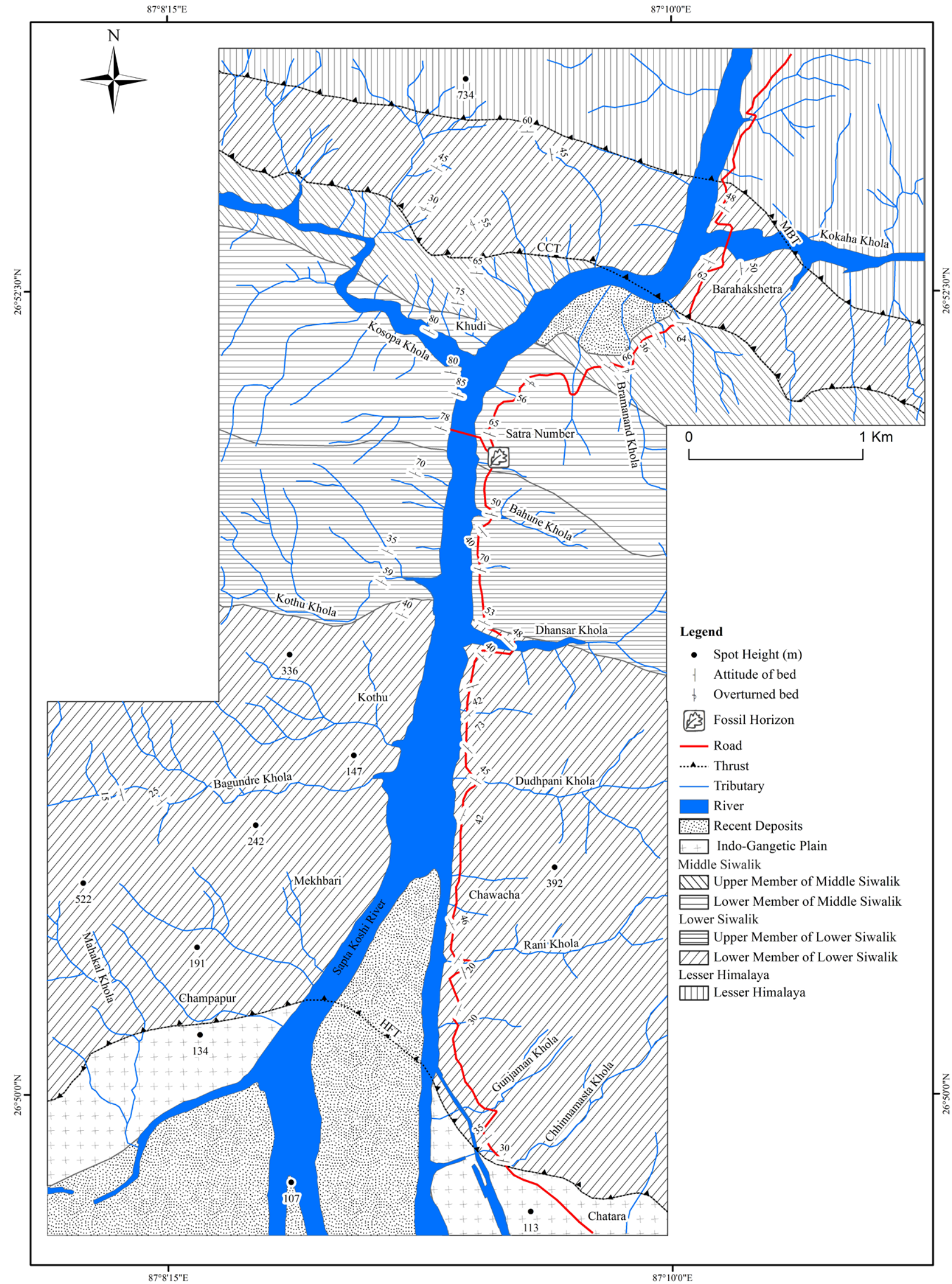

Fig. 2: Geological map of study area showing the fossil locality (Adhikri 2017). 


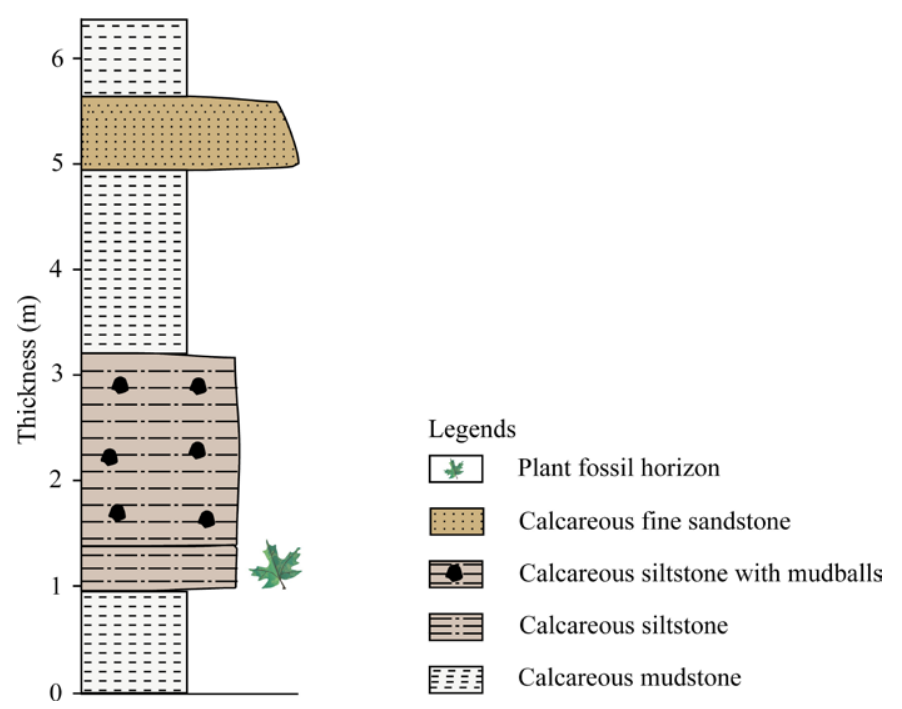

Fig. 3: Lithological details of the fossil horizon at the ChataraBarahakshetra road section, Satra Number.

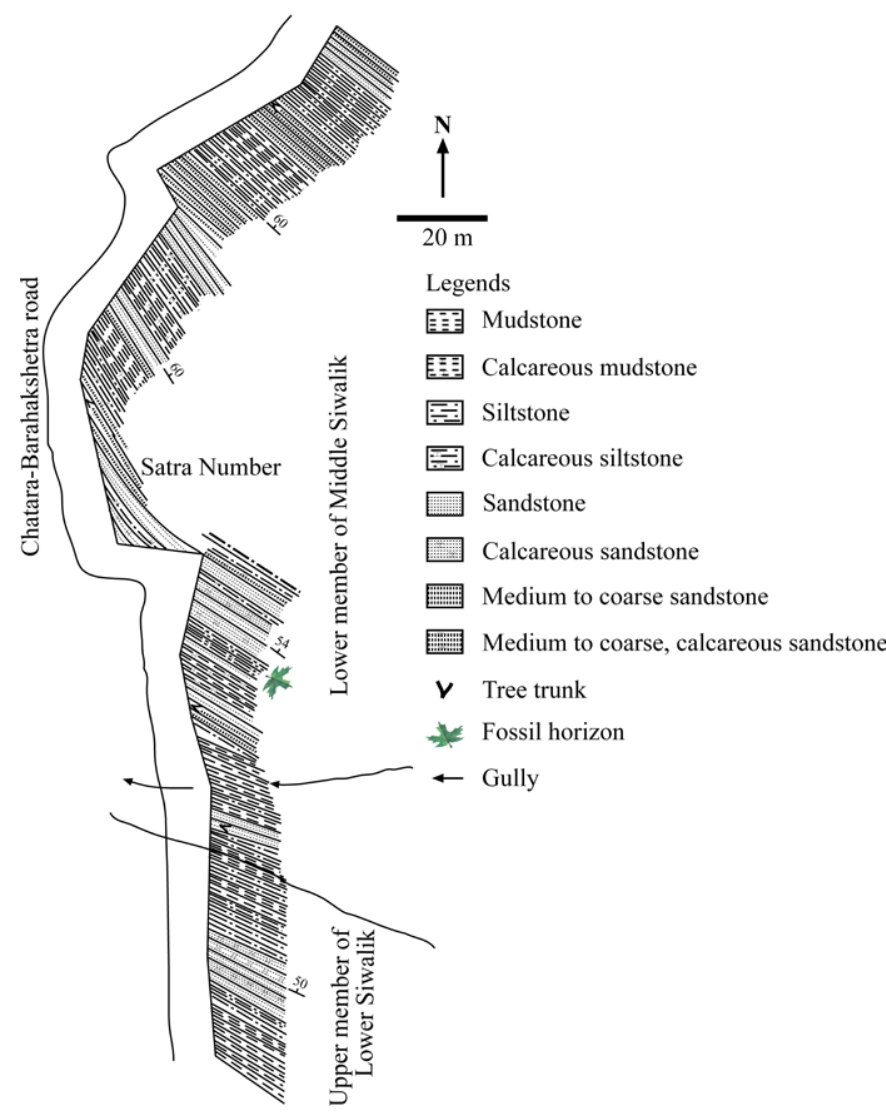

Fig. 4: Geological route map along the Chatara-Barahakshetra road section showing the fossil horizon.

\section{MATERIAL AND METHODS}

Material for present study was collected by one of us (PA) from the Siwalik sediment of the Chatara-Barahakshetra area, eastern Nepal. The specimens were cleared with the help of chisel and hammer and photographed under the natural low angled light using a Canon digital camera SX110. For describing the fossil leaves, terminology proposed by Dilcher (1974), and Ellis et al. (2009) was followed. The specimens were compared and identified in the herbarium of Central National Herbarium (CNH), Howrah, India. All the specimens are stored at the Central Department of Geology Museum (CDGM), Tribhuvan University, Kirtipur, Kathmandu, Nepal.

\section{RESULTS}

\section{(1). Systematics}

Order: Myrtales

Family: Combretaceae

Genus: Terminalia L.

Species: Terminalia sp.

Figures: Plate I (Fig. a)

Number of specimens examined: One

Figured specimen no.: $17 \mathrm{~N} 10 \mathrm{a}$

Locality: Chatara-Barahakshetra road section, Satra Number $\left(26^{\circ} 52^{\prime} 00^{\prime \prime} \mathrm{N}, 87^{\circ} 09^{\prime} 23^{\prime \prime} \mathrm{E}\right)$.

Stratigraphic horizon: Lower member of Middle Siwalik.

Age: Late Miocene.

\section{Description}

Leaf incomplete, narrow elliptic, seemingly symmetrical, preserved lamina length $8.56 \mathrm{~cm}$, maximum width $4.9 \mathrm{~cm}$; apex and base broken; margin entire; texture chartaceous; venation pinnate, eucamptodromus; primary vein thickness stout, straight; secondary vein about eight pairs visible, simple, alternate and opposite, 0.8-1.9 cm apart, angle of divergence moderate acute $\left(57^{\circ}-64^{\circ}\right)$, more or less uniform, moderately thick, abruptly curved up near the margin; intersecondary veins not observed; tertiary veins percurrent and recurved, angle of origin RA; marginal venation pattern fimbriate; further details not observed.

\section{Affinities}

The characteristics features of fossil leaf such as elliptic shape, symmetrical lamina, entire margin, pinnate, eucamptodromous venation, angle of divergence of secondary vein moderate acute, alternate and opposite, percurrent and recurved tertiary veins suggest its affinities with Terminalia (Plate I, Fig. b) of the family of the Combretaceae. Several herbarium specimens of the modern genus were studied in detail but due to incompleteness of the fossil it is difficult to identify it up to the specific level.

\section{Fossil records and comparison}

Several fossil leaves of Terminalia have been described from the Cenozoic sediments of Nepal and India by Lakhanpal (1970); Lakhanpal and Guleria (1981); Awasthi (1982); Tripathi and Tiwari (1983); Bande and Prakash (1984); Awasthi and Prasad (1990); Bande and Srivastava (1990); Prasad (1990, 1994a, 1994b, 1994c); Ambwani (1992); Lakhanpal and Awasthi (1992); Awasthi and Mehrotra (1995); Antal and Prasad (1998); Singh and Prasad (2007). Similarly several fossil wood of the genus Terminalioxylon have been 

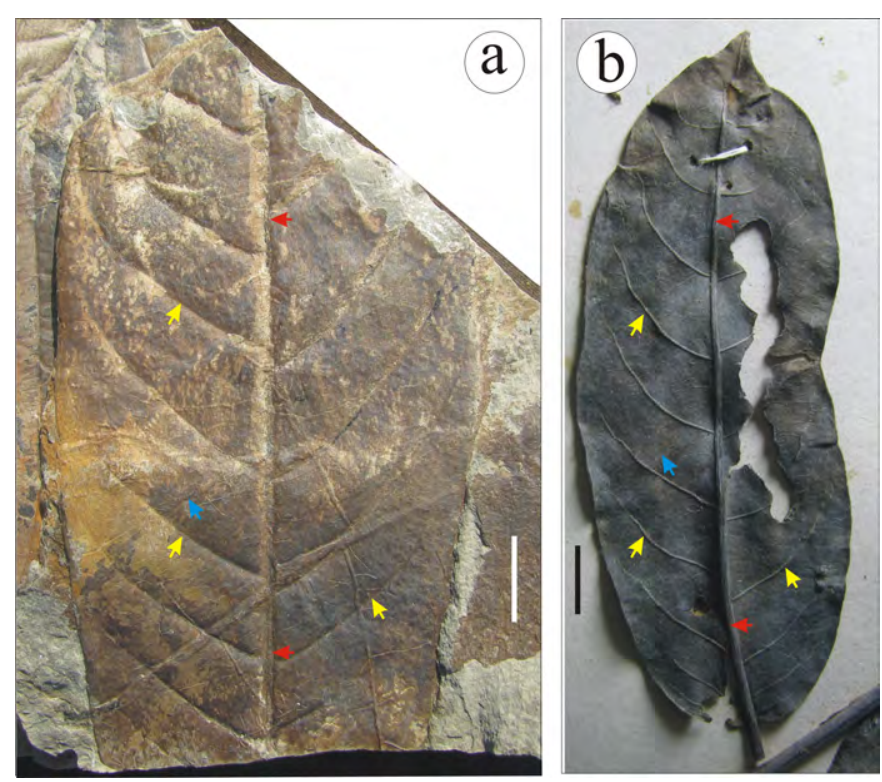

Plate I: a. Fossil leaf Terminalia sp. showing shape, size, and venation pattern such as primary vein (red arrow), secondary vein (yellow arrow) and tertiary vein (blue arrow) b. A modern leaf Terminalia paniculata showing similar shape, size, and venation pattern $(\mathrm{CNH}$ herbarium sheet No. 554928) as in fossil such as primary vein (red arrow), secondary vein (yellow arrows) and tertiary vein (blue arrow). Scale bar $=1 \mathrm{~cm}$.
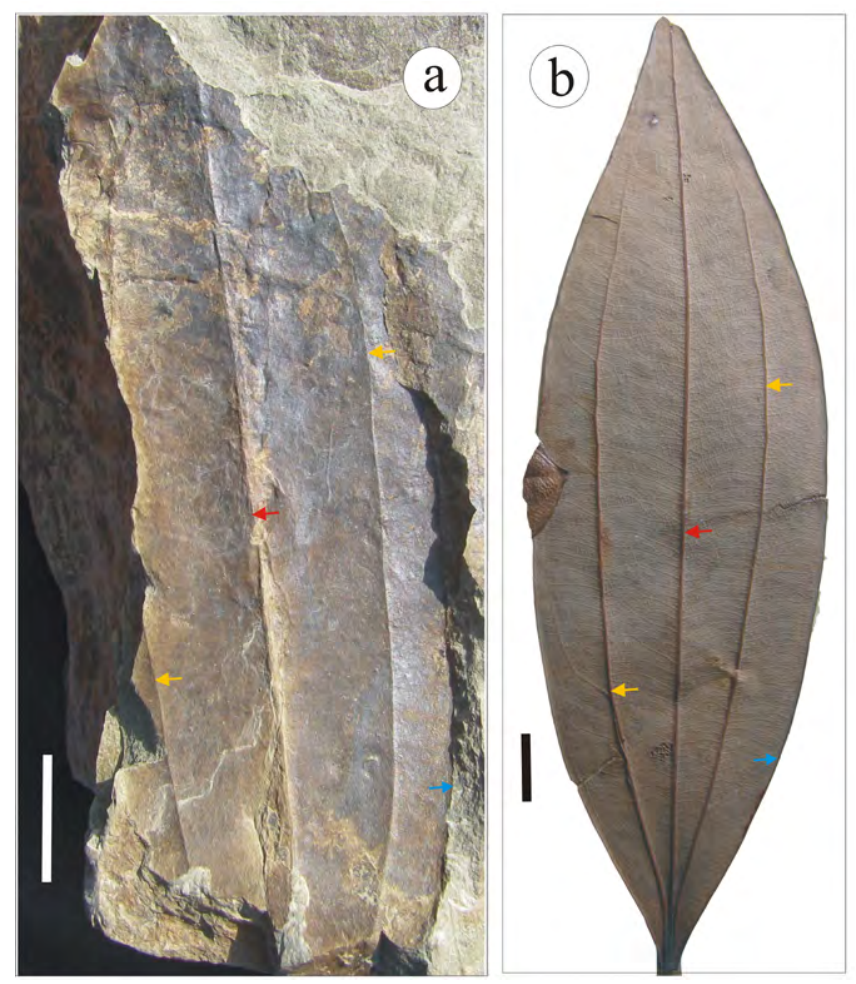

Plate II: a. Fossil leaf Daphnogene makumensis showing shape, size, and venation pattern such as primary vein (red arrow), lateral primary vein (yellow arrow) and entire margin (blue arrow) b. A modern leaf of Cinnamomum tamala showing similar shape, size, and venation pattern (CNH herbarium sheet No. 383551) as in fossil such as primary vein (red arrow), lateral primary vein (yellow arrows) and entire margin (blue arrow). Scale bar $=1 \mathrm{~cm}$. described from the Cenozoic sediment of India (Mahabale and Deshpande 1965; Ramauyjum 1966; Prakash 1966; Guleria 1983; Shukla et al. 2013). A fossil fruit of Terminalia has also been described from the Eocene of India by Singh et al. (2010) while pollen of Terminalia has been recorded from the Siwalik sediments of Nepal by Paudayal (2012).

\section{(2). Systematics}

Order: Laurales

Family: Lauraceae

Genus: Daphnogene Unger

Species: D. makumensis Mehrotra, Dilcher, and Lott

Figures: Plate II (Fig. a)

Number of specimens examined: One

Figured specimen nos.: $17 \mathrm{~N} 15 \mathrm{~b}$

Locality: Chatara-Barahakshetra road section, Satra Number $\left(26^{\circ} 52^{\prime} 00^{\prime \prime} \mathrm{N}, 87^{\circ} 09^{\prime} 23^{\prime \prime} \mathrm{E}\right)$.

Stratigraphic horizon: Lower member of Middle Siwalik.

Age: Late Miocene.

\section{Description}

Leaf incomplete, narrow elliptic, preserved lamina length $7.8 \mathrm{~cm}$, maximum width $2.6 \mathrm{~cm}$; apex and base broken; margin entire; texture chartaceous; venation acrodromous; mid vein moderately thick, markedly curved, one pair of lateral veins probably arising from the base of the lamina and running parallel to the midvein with equal distance from the margin and midvein, thin; further details not preserved.

\section{Affinities}

The characteristics features of the fossil leaf such as narrow elliptic shape, entire margin, acrodromous venation, lateral veins equidistance to mid vein and running convergently at distal portion suggest its affinities with Cinnamomum Schaeffer, Cryptocarya R. Brown, Lindera Thunb., and Neocinnamomum $\mathrm{H}$. Liou of the family Lauraceae. As the fossil leaf is incomplete, it is difficult to identify it up to the generic level. It has been suggested that the fossils leaves which are incomplete with the features such as acrodromous venation, lateral vein parallel and equidistance to midvein and running convergently at distral portion can be placed in Daphnogene. After making detailed comparison with them, the fossil specimen shows resemblance with the leaf Cinnamomum tamala Buch.- Ham. (Plate II, Fig. b).

\section{Fossil record and comparison}

Leaves of the genus Cinnamomum are also known from the Siwalik sediments of Nepal and India (Lakhanpal and Awasthi 1984; Prasad 1990; Antal and Awasthi 1993; Shashi et al. 2007; Prasad and Pandey 2008, Khan and Bera 2014). Cinnamomum sp. is known from the middle Miocene of the Kerala Coast, India (Awasthi and Srivastava 1992). Daphnogene makumensis Mehrotra, Dilcher, and Lott is described from the Oligocene sediments of Assam, India (Mehrotra et al. 2009). The present fossil shows maximum similarity with Daphnogene 
makumensis Mehrotra, Dilcher, and Lott and therefore, the present fossil has been placed into the same species. The fossil woods of Cinnamomum have been assigned to Laurinoxylon from the Miocene to Pliocene sediments of India (Prakash and Tripathi 1974; Bande and Prakash 1980; Lakhanpal et al. 1981; Awasthi and Ahuja 1982).

\section{DISSCUSSION AND CONCLUSION}

The genus Terminalia Linn. comprises about 150 species, which are large trees distributed widely in the tropics of Africa, America, and Asia, extending to South Africa, Australia, and Pacific Islands (Shu 2007). In Nepal Himalaya, five species are known to exist at the range of 200-1400 m amsl. (Press et al. 2000). Similarly, Cinnamomum tamala Bauch.- Ham. is an evergreen tree growing up to $20 \mathrm{~m}$ in height. It is distributed throughout the sub-tropical region of west Yunnan, Nepal, India, Bhutan etc. at 1100-2000 m (Gui 2008). The habit, habitat and the present day distribution of the comparable extant taxa indicate the existence of tropical to sub-tropical evergreen to semi evergreen forest with humid climate. Thus, it may be concluded that probably a humid climate prevailed in Chatara-Barahakshetra area at the time of deposition in contrast to present day relatively dry climate.

\section{ACKNOWLEDGEMENTS}

DA, KNP, KS and PA are thankful to the Head of Department, Central Department of Geology, Tribhuvan University, while GS and RCM are thankful to the Director, Birbal Sahni Institute of Paleosciences for providing necessary facilities for this research. They are also grateful to Director, Central National Herbarium, Howrah (India) for permission to access its herbarium. PA would like to thank for Master's Thesis grant from the Chinese Academy of Sciences (CAS), Beijing for supporting this research.

\section{REFERENCES}

Adhikari, P., 2017. Geology and paleontology of ChataraBarahakshetra area, eastern Nepal. M.Sc. dissertation, Central Department of Geology, Tribhuvan University, Nepal, (Unpublished), $83 \mathrm{p}$.

Adhikari, S.K., and Sakai, T., 2017. Petrography of the Neogene Siwalik Group sandstones, Khutia Khola section, Nepal Himalaya: implications for provenance, paleoclimate and tectonic setting. Jour. Nepal Geol. Soc., v. 53, pp. 17-30.

Ambwani, K., 1992. Leaf impression belonging to the Tertiary age of north east India. Phytomorphology, v. 41(1-2), pp. 139-146.

Antal, J.S., and Awasthi, N., 1993. Fossil flora from the Himalayan foot-hills of Darjeeling District, west Bengal and its palaeoecological and phytogeographical significance. Palaeobotanist, v. 42, pp. 14-60.

Antal, J.S., and Prasad, M., 1998. Morphotaxonomic study of some more fossil leaves from the Lower Siwalik sediments of west Bengal, India. Palaeobotanist, v. 47, pp. 88-98.

Auden, J.B., 1935. Traverses in the Himalaya. Record of Geological Survey of India, v. 69, pp. 123-167.

Awasthi, N., 1982. Tertiary plant megafossils from the Himalaya: a review. Palaeobotanist, v. 30(3), pp. 254-267.

Awasthi, N., and Ahuja, M., 1982. Investigations of some carbonized woods from the Neogene of Varkala in Kerala Coast. Geophytology, v. 12, pp. 245-259.

Awasthi, N., and Mehrotra, R.C., 1995. Oligocene flora from Makum Coalfield, Assam, India. Palaeobotanist, v. 44, pp. 157-188.

Awasthi, N., and Prasad, M., 1990. Siwalik plant fossils from Surai Khola area, western Nepal. Palaeobotanist, v. 38, pp. 298-318.

Awasthi, N., and Srivastava, R., 1992. Fossil leaves and a fruit from Warkalli beds, Kerala Coast, India. Geophytology, v. 21, pp. 53-57.

Bande, M.B., and Prakash, U., 1980. Four new fossil dicotyledonous woods from the Deccan intertrappean beds near Shahpura, Mandla District, Madhya Pradesh. Geophytology, v. 10, pp. 268-271.

Bande, M.B., and Prakash, U., 1984. Occurrence of Evodia, Amoora and Sonneratia from the Palaeogene of India. Proceeding of symposium on evolutionary botany and biostratigraphy (Eds. Sharma, A.K., Mitra, G.C., and Banerjee, M.) Today and Tomorrow Printers and Publishers, New Delhi, pp. 97-144.

Bande, M.B., and Srivastava, G.P., 1990. Late Cenozoic plant impressions from Mahuadanr Valley, Palamu District, Bihar. Palaeobotanist, v. 37(3), pp. 331-366.

Bashyal, R.P., 1980. Gondwana type of formation with phosphatic rocks in S.E. Nepal. Jour. Geol. Soc. India, v. 21, pp. 489-491.

Corvinus, G., and Nanda, A.C., 1994. Stratigraphy and palaeontology of the Siwalik Group of the Surai Khola and Rato Khola in Nepal. Neues Jahrbuch für Geologie und Paläontologie, Stuttgart, v. 191(1), pp. 25-68.

Corvinus, G., and Rimal, L.N., 2001. Biostratigraphy and geology of the Neogene Siwalik Group of Surai Khola and Rato Khola areas in Nepal. Paleogeography, Paleoclimatology, Paleoecology, v. 165, pp. 251-279.

Dhakal, S., 2001. Geological investigation of the ChataraBarahakshetra area, Eastern Nepal. M. Sc. Thesis submitted by Central Department of Geology, Tribhuvan University, Kritipur, Kathmandu (Unpublished), pp. 1-43.

Dhital, M.R., 1992. Lithostratigraphic comparison of three diamictite successions of Nepal Lesser Himalaya. Jour. Nepal Geol. Soc., v. 8 , pp. $43-54$.

Dhital, M.R., 2015, Geology of the Nepal Himalaya: regional perspective of the classic colloidal origin. Springer, Switzerland, $499 \mathrm{p}$.

Dhital, M.R., Gajurel, A.P., Pathak, D., Paudel, L.P., and Kizaki, K., 1995. Geology and structure of the Siwaliks and Lesser Himalaya in Surai Khola-Bardanda area, mid-western Nepal. Bull. Dept. Geol., Tribhuvan University, Kathmandu, Nepal, v. 4, pp. 1-70.

Dilcher, D.L., 1974. Approaches to the identification of angiosperm leaf remains. Bot. Rev., v. 40, pp. 1-157.

Ellis, B., Daly, D.C., Hickey, L.J., Johnson, K.R., Mitchell, J.D., Wilf, P., and Wing, S.L., 2009. Manual of leaf architecture. Ithaca and New York, pp. 1-190.

Gansser, A., 1964. Geology of the Himalayas. Interscience, New York, $289 \mathrm{p}$.

Gui, C., 2008. Cinnamomum tamala (Buchanan-Hamilton). Flora of China, v. 7, pp. 177-178.

Guleria, J.S., 1983. Some fossils woods from the Tertiary of Districts Kachchh, western India. Palaeobotanist, v. 31(1), pp. 109-128.

Hagen, T., 1969. Report on the geological survey of Nepal. Volume 1: preliminary reconnaissance. Denkschiiften der Schweizerischen Naturforschenden Gesellschaft, Band LXXXVI/1, pp. 1-185.

Hoorn, C., Ohja, T., and Quade, J., 2000. Palynological evidence for vegetation development and climatic change in the SubHimalayan Zone (Neogene, central Nepal). Palaeogeography, Palaeoclimatology, Palaeoecology, v. 163, pp. 133-161. 
Itihara, M., Shibasaki, T., and Miyamoto, N., 1972. Photogeological survey of the Siwalik Ranges and the Terai Plain, southeastern Nepal. Jour. Geosci., Osaka City University, v. 15(4), pp. 7798.

Joshi, G.R., and Dwivedi, S.K., 2003. Geological and Sedimentological study of the Bhasu area, Sub Himalaya, far western Nepal. Jour. Strat. Asso. Nepal, v. 4 (Sp. Issue), pp. 32-43.

Kaphle, K.P., and Einfalt, H.C., 1992. Occurrence of volcanites in the Lower Siwalik Formation, an evidence of Late Tertiary igneous activity in the central Siwalik of Nepal. Jour. Nepal Geol. Soc., v. 8 , pp. 11-20.

Khan, M.A., and Bera, S., 2014. New lauraceous species from the Siwalik forest of Arunachal Pradesh, eastern Himalaya, and their palaeoclimatic and palaeogeographic implications. Turkish Jour. Bot., v. 38, pp. 453-464.

Konomatsu, M., 1997. The mode of occurrence of leaf-fossils in the Churia (Siwalik) Group of west central Nepal. Jour. Geosci. Osaka City University, v. 40(8), pp. 145-152.

Konomatsu, M., and Awasthi, N., 1999. Plant fossils from Arung Khola and Binai Khola formations of Churia Group (Siwalik), west central Nepal and their palaeoecological and phytogeographical significance. Palaeobotanist, v. 48, pp. 163-181.

Lakhanpal, R.N., 1970. Tertiary flora of India and their bearing on the historical geology of the region. Taxon, v. 19(5), pp. 675-694.

Lakhanpal, R.N., and Awasthi, N., 1984. A late Tertiary flora from near Bhikhnathoree in west Champaran District, Bihar. Current Trends of Life Sciences, v. 10, pp. 587-596.

Lakhanpal, R.N., and Awasthi, N., 1992. New species of Fissistigma and Terminalia from the Siwalik sediments of Balugoloa, Himachal Pradesh. Geophytology, v. 21, pp. 49-52.

Lakhanpal, R.N., Prakash, U., and Awasthi, N., 1981. Some more dicotyledonous woods from the Tertiary of Deomali, Arunachal Pradesh, India. Palaeobotanist, v. 27, pp. 232-252.

Lombard, A., 1958. Un itinéraire géologique dans l'Est du Népal (Massif du Mont Everest). Mémoires Société Helvétique Sciences Naturelles, v. 82, pp. 1-107.

Mahabale, T.S., and Deshpande, S.R., 1965. Terminalioxylon tomentosum sp. nov., a fossil wood from Ghala (Gujrat state) belonging to family Combretaceae. Botanical Survey of India, v. 7(1-4), pp. 267-270.

Martin, A.J., DeCelles, P.G., Gehrels, G.E., Patchett, P.J., and Isachsen, C. 2005. Isotopic and structural constraints on the location of the Main Central Thrust in the Annapurna Range, central Nepal Himalaya. Geol. Soc. America Bull., v. 117, pp. 926-944.

Mehrotra, R.C., Dilcher, D.L., and Lott, T.A., 2009. Notes on elements of the Oligocene flora from the Makum coalfield, Assam, India. Palaeobotanist, v. 58, pp. 1-9.

Munthe, J., Dongol, B., Hutchison, J.H., Kean, W.F., Munthe, K., and West, R.M., 1983. New fossil discoveries from the Miocene of Nepal include a Hominoid. Nature, v. 303, pp. 331-333.

Nakayama, K., and Ulak, P.D., 1999. Evolution of the fluvial style in the Siwalik Group in the foothills of Nepal Himalaya. Sed. Geol., v. 125, pp. 205-224.

Paudayal, K.N., 2012. Middle to Late Miocene vegetation and climate from the Siwalik sediments (Karnali River section), far western Nepal. Jour. Nepal Geol. Soc., v. 44, pp. 33-44.

Paudayal, K.N., 2013a. Palaeoclimatic significance of palynological assemblanges from the Siwalik sediments in Dhudhaura Khola section, central Nepal. Jour. Nepal Geol. Soc., v. 46, pp. 111120.

Paudayal, K.N., 2013b. Palynology of the Baka Formation (Middle Siwalik), Karnali River section far west Nepal. Jour. Inst. Sci. Tech., IOST, TU, v. 18(1), pp. 65-70.
Prakash, U., 1966. Wood of Terminalia tomentosa Wt. and Arn. from the Tertiary of Nagaland. Publication centre of advanced studies geology, Panjab University, Chandigrh, v. 3, pp. 27-31.

Prakash, U., and Tripathi, P.P., 1974. Fossil woods from the Tertiary of Assam. Palaeobotanist, v. 21, pp. 305-316.

Prasad, M., 1990. Fossil flora from the Siwalik sediment of Koilabas, Nepal. Geophytology, v. 19, pp. 79-105.

Prasad, M., 1994a. Angiospermous leaf remains from the Siwalik sediments of Haridwar, Uttar Pradesh and their bearing on palaeoclimate and phytogeography. Him. Geol., v. 15, pp. 8394.

Prasad, M., 1994b. Siwalik (Middle-Miocene) woods from the Kalagarh area in the Himalayan foot hills and their bearing on palaeoclimate and phytogeography. Rev. Palaeobot. Palyno., v. 76, pp. 49-82.

Prasad, M., 1994c. Siwalik (Middle-Miocene) leaf impressions from the foot hills of the Himalaya, India. Tertiary Research, v. 15, pp. 53-90.

Prasad, M., and Khare, E.G., 2004. Cuticular studies on the fossil leaves from Churia (Siwalik) sediments of Arjun Khola sequence, western Nepal. Palaeobotanist, v. 53, pp. 105-112.

Prasad, M., and Pandey, S.M., 2008. Plant diversity and climate during Siwalik (Miocene-Pliocene) in the Himalayan foot Hills of western Nepal. Palaeontographica B, v. 278, pp. 13-70.

Prasad, M., and Pradhan, U.M.S., 1998. Studies on plant fossils from the Siwalik sediments of far eastern Nepal. Palaeobotanist, v. 48, pp. 99-109.

Prasad, M., Antal, J.S., Tripathi, P.P., and Pandey, V.K., 1999. Further contribution to the Siwalik flora from the Koilabas area, western Nepal. Palaeobotanist, v. 48, pp. 49-95.

Prasad, M., Pradhan, U.M.S., and K.C., S., 1997. Fossil wood of Duabanga from the Siwalik of Sindhuli area, eastern Nepal. Jour. Nepal Geol. Soc., v. 15, pp. 39-43.

Press, J.R., Shrestha, K.K., and Sutton, D.A., 2000. Annotated checklist of the flowering plants of Nepal. The Natural History Museum, London, $430 \mathrm{p}$.

Ramanujam, C.G.K., 1966. On the two species of Terminalioxylon Schonfeld from the Tertiary of south Arcot District, Madras. Jour. Indian Bot. Soc., v. 35(1), pp. 103-113.

Sah, R.B., Shrestha, D., and Gorkhali, S., 2000a. Geology and plant fossils from the Siwaliks of Godavari area, Sub-Himalaya, farwestern Nepal. Jour. Strat. Asso. Nepal, v. 2, pp. 42-52.

Sah. R.B., Shrestha P.M., Mulmee, M.R., and Budhathoki, R., $2000 \mathrm{~b}$. Geology and new fossils record of an extict elephant from the Siwalik succession of Rato Khola area, Sub- Himalaya, eastern Nepal. Jour. Strat. Asso. Nepal, v. 2, pp. 29-41.

Sah, R. B., Thakuri, N., and Yadav, B., 2000c. Lithostratigraphy of Siwalik succession of Katari area, Sub-Himalaya, eastern Nepal. Jour. Strat. Asso. Nepal, v. 2, pp. 18-28.

Sah, R.B., Ulak, P.D., Gajurel, A.P., and Rimal, L.N., 1994. Lithostratigraphy of the Siwalik sediments of the AmlekhganjHetauda area, Sub-Himalaya of Nepal. Him. Geol., v. 15, pp. 37-48.

Sarkar, S., 1990. Siwalik pollen succession from Surai Khola of western Nepal and its reflection on palaeoecology. The Paleobotanist, v. 38, pp. 319-324.

Schelling, D., 1992. A balanced cross section through the eastern Nepal Siwalik Hills, Bagmati River region, implication for the structure of the southern Himalaya. Jour. Nepal Geol. Soc., v. 8, pp. 1-10.

Shashi, Pandey, S.M., and Tripathi, P.P., 2007. Siwalik (Middle Miocene) leaf impressions from Tanakpur area, Uttaranchal and their bearing on Climate. Geophytology, v. 37(1-2), pp. 99107. 
Shu, H.Z., 2007. Terminalia Linnaeus, Syst. Nat. Flora of China, v. 14, pp. 310-314.

Shukla, A., Mehrotra, R.C., and Guleria, J.S., 2013. Two dicotyledonous woods from the late Neogene sediments of Jaisalmer, Rajasthan. Palaeobotanist, v. 62(1), pp. 11-17.

Sigdel, A., Sakai, T., Ulak, P.D., Gajurel, A.P., and Upreti, B.N., 2011. Lithostratigraphy of the Siwalik Group, Karnali River section, far-west Nepal Himalaya. Jour. Nepal Geol. Soc., v. 43 (Sp. Issue), pp. 83-101.

Singh, S.K., and Prasad, M., 2007. Late Tertiary leaf flora of mahuadanr valley, Jharkhand. Jour. Palaeont. Soc. India, v. 52(2), pp. 175-194.

Singh, H., Prasad, M., Kumar, K., Rana, R.S., and Singh, S.K., 2010. Fossil fruits from early Eocene Vastan Lignite, Gujarat, India: taphonomic and phytogeographic implications. Current Science, v. 98(12), pp. 1625-1632.

Tokuoka, T., and Yoshida, M., 1984. Some characteristics of Siwalik (Churia) Group in Chitwan Dun, central Nepal. Jour. Nepal Geol. Soc., v. 4 (Sp. Issue), pp. 26-55.

Tokuoka, T., Takayasu, K., Hisatomi, K., Yamasaki, H., Tanaka, S., Konomatu, M., Sah, R.B., and Ray, S.M., 1990. Stratigraphy and geological structures of the Churia (Siwalik) Group in the Tinau Khola-Binai Khola area, west central Nepal. Memorier Faculty of Science, Shimane University, v. 24, pp. 71-88.

Tokuoka, T., Takayasu, K., Yoshida, M. and, Hisatomi, K., 1986. The Churia (Siwalik) Group of Arung Khola area, west central Nepal. Memorier Faculty of Science Shimane University, v. 20, pp. 135-210.

Tokuoka, T., Takeda, S., Yoshida, M., and Upreti, B.N., 1988. The Churia (Siwalik) Group in the western part of the Arung Khola area, west central Nepal. Memorier Faculty of Science Shimane University, v. 22, pp. 131-140.
Tripathi, P.P., and Tiwari, V.D., 1983. Occurrence of Terminalia in the Lower Siwalik beds near Koilabas, Nepal. Current Science, v. 52, pp. 167.

Ulak, P.D., 2002. Palaeohydrology of the Siwalik Group along the Bakiya Khola section, central Nepal Himalaya. Jour. Nepal Geol. Soc., v. 26, pp. 49-58.

Ulak, P.D., 2004. Evolution of fluvial system in Siwalik Group of Chatara-Barahakshetra area, east Nepal Himalaya. Jour. Nepal Geol. Soc., v. 30, pp.67-74.

Ulak, P.D., 2009. Lithostratigraphy and fluvial style of the Siwalik Group along Kankai Khola section, east Nepal Himalaya. Bull, Dept. Geol., Tribhuvan University, Kathmandu, Nepal, v. 8, pp. 63-74.

Ulak, P.D., and Nakayama, K., 1998. Lithostratigraphy and evolution of the fluvial style in the Siwalik Group in the Hetauda-Bakiya Khola area, central Nepal. Bull. Dept. Geol., Tribhuvan University, v. 6, pp. 1-14.

Valdiya, K.S., 2002. Emergence and evolution of Himalaya: reconstructing history in the light of recent studies. Progress in Physical Geography, v. 26(3), pp. 360-399.

West, R.M., and Munthe, J., 1981. Neogene vertebrate paleontology and stratigraphy of Nepal. Jour. Nepal Geol. Soc., v. 1(1), pp. $1-14$.

West, R.M., Hutchison, J., and Munthe, J., 1991. Miocene vertebrates from the Siwalik Group, western Nepal. Jour. Vert. Paleont., v. 11(1), pp. 108-129.

West, R.M., Lukacs, J.R., Munthe, J., and Hussain, S.T., 1978. Vertebrate fauna from Neogene Siwalik Group, Dang valley, western Nepal. Jour. Paleont., v. 52(5), pp. 1015-1022.

Yoshida, M., and Arita, K., 1982. On the Siwalik observed along some routes in central Nepal. Jour. Nepal Geol. Soc., v. 2, pp. 59-66. 